\title{
Grain iron and zinc density in pearl millet: combining ability, heterosis and association with grain yield and grain size
}

\author{
Anand Kanatti ${ }^{1,2}$, Kedar N Rai $^{1 *}$, Kommineni Radhika ${ }^{2}$, Mahalingam Govindaraj ${ }^{1}$, Kanwar L Sahrawat ${ }^{1}$
} and Aluri S Rao ${ }^{1}$

\begin{abstract}
Genetics of micronutrients and their relationships with grain yield and other traits have a direct bearing on devising effective strategies for breeding biofortified crop cultivars. A line $\times$ tester study of 196 hybrids and their 28 parental lines of pearl millet (Pennisetum glaucum (L.) R.Br.) showed large genetic variability for Fe and Zn densities with predominantly additive gene action and no better-parent heterosis. Hybrids with high levels of Fe and Zn densities, involved both parental lines having significant positive general combining ability (GCA), and there were highly significant and high positive correlations between performance per se of parental lines and their GCAs. There was highly significant and high positive correlation between the Fe and Zn densities, both for performance per se and GCA. Fe and Zn densities had highly significant and negative, albeit weak, correlations with grain yield and highly significant and moderate positive correlation with grain weight in hybrids. These correlations, however, were non-significant in the parental lines. Thus, to breed hybrids with high Fe and Zn densities would require incorporating these micronutrients in both parental lines. Also, simultaneous selection for Fe and $\mathrm{Zn}$ densities based on performance per se would be highly effective in selecting for GCA. Breeding for high Fe and Zn densities with large grain size will be highly effective. However, combining high levels of these micronutrients with high grain yield would require growing larger breeding populations and progenies than breeding for grain yield alone, to make effective selection for desirable recombinants.
\end{abstract}

Keywords: Pearl millet; Micronutrients; Grain yield; Genetic variability; Hybrids; Heterosis; Correlation

\section{Introduction}

Micronutrient malnutrition resulting from dietary deficiency of one or more micronutrients has been recognized as a serious human health problem worldwide. The most striking of these are iron $(\mathrm{Fe})$ and zinc $(\mathrm{Zn})$ deficiencies that rank $9^{\text {th }}$ and $11^{\text {th }}$, respectively, among the top 20 risk factors contributing to global burden of disease (WHO 2002). Pharmaceutical supplementation, industrial fortification and dietary diversification are some of the interventions that have been used to address this problem. Notwithstanding the recurring cost, the impact of supplementation and fortification in the developing countries remains limited because of poor infrastructure

\footnotetext{
*Correspondence: k.rai@cgiar.org

'International Crops Research Institute for Semi-Arid Tropics (ICRISAT),

Patancheru, Hyderabad 502324, Telangana, India

Full list of author information is available at the end of the article
}

and delivery system (Stein et al. 2005). Dietary diversification raises an issue of diverse food affordability since a sharp increase in food prices will have a large impact on poor households. It also has problem of consumer acceptance in case dietary diversification calls for including foods which are not a part of conventional diets. Biofortification of staple crops, especially for mineral micronutrients, is a sustainable and cost-effective approach. It has great promise for improving the mineral nutritional status and health of poor populations in both rural and urban areas of the developing world (Bouis 2003). Biofortified cultivars of staple crops improved for mineral micronutrients are also readily acceptable to consumers as their adoption does not call for change in dietary habits.

Pearl millet (Pennisetum glaucum (L.) R. Br.) is a major warm-season cereal grown on 28 million ha for grain and fodder production in some of the most marginal areas of

\section{实}


the arid and semi-arid tropical regions of Asia and Africa. In these regions, pearl millet is a major source of dietary energy and mineral micronutrients. India is the largest producer of this crop with $>9$ million ha area and 8.5 million tons of grain production (Yadav et al. 2012). The contribution of pearl millet to the total $\mathrm{Fe}$ and $\mathrm{Zn}$ intake from all food sources has been reported to very widely vary across rural India. For instance, it was observed to be contributing $19-63 \%$ of the total Fe intake and $16-56 \%$ of the total $\mathrm{Zn}$ intake in parts of Rajasthan, Maharashtra and Gujarat states (Parthasarathy Rao et al. 2006). Large genetic variability for Fe and Zn density observed in the breeding lines, improved populations and germplasm (Velu et al. 2007, 2008a; Rai et al. 2012) provides for good prospects to breed improved pearl millet cultivars with elevated levels of these micronutrients. The International Crops Research Institute for the Semi-Arid Tropics (ICRISAT), supported by HarvestPlus Challenge Program of the Consultative Group on International Agricultural Research (CGIAR), and in partnership with the public and private sector breeding program in India, has undertaken a major initiative to develop high-yielding hybrids with high levels of Fe and Zn density in pearl millet.

Pearl millet is a highly cross-pollinated crop with openpollinated varieties (OPVs) and hybrids as the two broad cultivar options. Hybrids are the most dominant cultivars in India, occupying $>70 \%$ of area under improved pearl millet cultivars, with OPVs cultivated on limited scales. A preliminary study showed about two-fold differences for $\mathrm{Fe}$ and $\mathrm{Zn}$ densities among pearl millet hybrids under cultivation in India, with Fe density varying from 31 to $61 \mathrm{mg} \mathrm{kg}^{-1}$ and $\mathrm{Zn}$ density varying from 32 to $54 \mathrm{mg} \mathrm{kg}^{-1}$ (Rai et al. 2013). An understanding of the nature of genetic variability and heterosis will have a direct bearing on devising effective hybrid breeding strategies for Fe and $\mathrm{Zn}$ density. There is limited information on genetic variability and heterosis for Fe and Zn density in pearl millet (Velu et al. 2011b; Govindaraj et al. 2013). While improving the Fe and $\mathrm{Zn}$ densities, it is important that genetic gains for these micronutrients are not made at the expense of grain yield and grain size. The main objective of this research was to examine the nature of genetic variability in relation to heterosis for $\mathrm{Fe}$ and $\mathrm{Zn}$ density. Since, there exists a wealth of literature on genetic variability and heterosis for grain yield and grain size (Khairwal et al. 1999), genetic variability and heterosis for these two traits were studied in the specific context of their associations with $\mathrm{Fe}$ and $\mathrm{Zn}$ densities.

\section{Material and methods}

\section{Genetic materials}

Fourteen maintainer lines (B-lines) used to as female parents (F), 14 restorer lines (R-lines) used as male parents (M), and 196 hybrids produced by $\mathrm{F} \times \mathrm{M}$ crosses during the 2010 summer season were included in this study. The parental lines of the hybrids were of diverse parentage (Table 1) with wide range of Fe and $\mathrm{Zn}$ densities, and differed for grain yield and various agronomic traits such as plant height, tillering, panicle size and 1000 -grain weight.

\section{Field trials}

The hybrids and parents were planted on 17-July during the 2011 rainy season (July to October) and on 24-January during 2012 summer season (January to April) at ICRISAT, Patancheru. Monthly mean temperatures varied from $20^{\circ} \mathrm{C}$ to $31^{\circ} \mathrm{C}$ and relative humidity from $50 \%$ to $93 \%$ during the rainy crop season. In the summer crop season, monthly mean temperatures varied from $16^{\circ} \mathrm{C}$ to $40^{\circ} \mathrm{C}$ and relative humidity from $22 \%$ to $79 \%$. Both trials were planted in randomized complete block design (RCBD) with three replications but in adjacent blocks. Sowing was done by tractor-mounted 4-cone planter (7100 US model). Each entry was planted in two rows of $2 \mathrm{~m}$ length, spaced at $75 \mathrm{~cm}$ between rows in rainy season and $60 \mathrm{~cm}$ in summer season. Overplanted plots were thinned $15 \mathrm{~d}$ after planting to single plants spaced $15 \mathrm{~cm}$ apart within each row. A basal dose of $100 \mathrm{~kg}$ of diammonium phosphate $(18 \% \mathrm{~N}$ and $46 \%$ P) was applied at the time of field preparation and $100 \mathrm{~kg}$ of urea $(46 \% \mathrm{~N})$ was applied as top dressing within 2 to $4 \mathrm{~d}$ after thinning. Fields were irrigated at 7 to $10 \mathrm{~d}$ intervals in summer crop season and twice in rainy crop season to ensure no moisture stress. All the recommended agronomic practices were followed for good crop growth. At the time of planting, four well spread representative soil samples were collected from the experimental fields from $0-30 \mathrm{~cm}$ layer and later bulked to prepare one composite sample for micronutrient analysis.

The plots of all the entries were harvested at or after physiological maturity (85-90 days after planting). During harvest, main panicles of five random plants from each plot were harvested and stored separately in a cloth bag to produce clean grain samples for micronutrient analysis. The remaining panicles of the plot were harvested as a bulk. These panicles were sundried for 10 to 15 days. While threshing, five separately harvested panicles mentioned above were manually threshed first and approximately $20 \mathrm{~g}$ of grains were collected for Fe and $\mathrm{Zn}$ analysis. The left over grains from these panicles were added to the bulk grain produced by threshing all the panicles of the plot in a multi-head machine thresher. The grain yield, including the $20 \mathrm{~g}$ sample taken for micronutrient analysis, was recorded for each plot and converted to $\mathrm{t} \mathrm{ha}^{-1}$ for grain yield analysis. A random sample of 200 grains for each entry was weighed to determine 1000 -grain weight. 


\begin{tabular}{|c|c|c|}
\hline $\mathrm{ID}^{\mathrm{a}}$ & $\begin{array}{l}\text { Female/Male } \\
\text { parents }^{\text {b }}\end{array}$ & Parentage $^{c}$ \\
\hline \multicolumn{3}{|c|}{ Female parents } \\
\hline 1 & ICMB 88004 & Togo-1 1-5-2 selection \\
\hline 2 & ICMB 92111 & $(81 \mathrm{~B} \times 843 \mathrm{~B})-11-1-1-\mathrm{B}$ \\
\hline 3 & ICMB 92888 & (843B× ICMPS 900-9-3-2-2)-41-2-6-2-2 \\
\hline 4 & ICMB 93222 & $(26 B \times 834 B)-11-2-B-B$ \\
\hline 5 & ICMB 97111 & HTBC-48-B-1-1-1-1 \\
\hline 6 & ICMB 98222 & ARD-288-1-10-1-2(RM)-5 \\
\hline 7 & ICMB 02555 & ICMV 87901-175-2-3-2-B-1 \\
\hline 8 & ICMB 04888 & $\begin{array}{l}\text { [(843B } \times \text { ICTP 8202-161-5)-20-3-B-B-3× B-lines } \\
\text { bulk]-2-B-1-3 }\end{array}$ \\
\hline 9 & ICMB 05555 & $\begin{array}{l}\text { [(BSECBPT/91-39x SPF3/S91-116)-15-2-1-4-4x } \\
\text { B-lines bulk]-1-B-4-1 }\end{array}$ \\
\hline 10 & ICMB 07555 & $\begin{array}{l}\text { [(843B } \times \text { ICTP 8202-161-5)-20-3-B-B-3× B-lines } \\
\text { bulk]-2-B-1 }\end{array}$ \\
\hline 11 & ICMB 07777 & $\begin{array}{l}\{\mathrm{ICMB} 99555 \times[(78-7088 / 3 / S E R 3 \text { AD//B282/(3/ } \\
4 \mathrm{~EB}) \times \mathrm{PBLN} / \mathrm{S} 95-359)-19-5-\mathrm{B}-\mathrm{B}]\}-13-2-\mathrm{B}-\mathrm{B}-\mathrm{B}-\mathrm{B}\end{array}$ \\
\hline 12 & ICMB 07999 & (HTBC-48-B-1-1-1-5× B-line bulk)-25-1-B-B \\
\hline 13 & ICMB 08222 & $\begin{array}{l}\text { [78-7088/3/SER3 AD//B282/(3/4)EB } \times \text { PBLN/S95- } \\
\text { 359]-19-2-B-1-B-B-3 }\end{array}$ \\
\hline 14 & ICMB 08333 & [ICMB 97444× (843B× 405B)-4]-1-2-B-B-B \\
\hline
\end{tabular}

\section{Male parents}

\begin{tabular}{|c|c|c|}
\hline 15 & PRP 1 & (EERC-HS-29)-B-12-4-1-1 \\
\hline 16 & PRP 2 & (EERC-HS-34)-B-7-2-3-2 \\
\hline 17 & PRP 3 & LaGrap C2-S1-38-2-1-1-1 \\
\hline 18 & PRP 4 & $\begin{array}{l}\text { (MC } 94 \text { C2-S1-3-2-2-2-1-3-B-BX SDMV } 90031 \\
\text { S1-93-3-1-1-3-2-B-2)-B-23-2-2 }\end{array}$ \\
\hline 1 & PRP 5 & AIMP 92901 S1-15-1-2-3-B-2-B-25-1-1 \\
\hline 2 & PRP 6 & $\begin{array}{l}\text { (MC } 94 \text { C2-S1-3-2-2-2-1-3-B-B× AIMP } 92901 \\
\text { S1-488-2-1-1-4-B-B)-B-8-3-1-3-B-B }\end{array}$ \\
\hline 21 & PRP 7 & Jakhrana $\times$ SRC II S2-215-3-2-1-B-3 \\
\hline 22 & PRP 8 & $\begin{array}{l}\text { (ICMS 7704-S1-127-5-1 × RCB-2 Tall )-B-19-3-2-1- } \\
\text { 1-1-B }\end{array}$ \\
\hline 3 & PRP 9 & MRC S1-9-2-2-B-B-4-B-B \\
\hline & IPC 616 & [J 260-1× 700557-1-4-10-5-1]-1-2-1-3 \\
\hline 2 & IPC 843 & {$[(J 834 \times 700516)]-1-4-4-2-4$} \\
\hline & IPC 1178 & (A $836 \times$ J 1798-32-2-2)-5-1-1 \\
\hline & IPC 1354 & EICP 8103-5 (Duplicate 001349) \\
\hline & IPC 390 & (F4FC 1498-1-1-3x J 104)-11-2-1-1 \\
\hline
\end{tabular}

${ }^{a} I D$ 1-14 female lines ( $B$ lines) and 15-28 male lines (R lines); ${ }^{b} / C M B$ ICRISAT Millet B-line; PRP Potential Restorer Parent; IPC ICRISAT Pollinator Collection; 'ICMPS ICRISAT Millet Pollinator for Smut resistance; HTBC High-Tillering B-Composite; ARD Appa Rao, Rai and Djaney; ICMV ICRISAT Millet Variety; ICTP ICRISAT Togo Patancheru; BSECBPT Bold-Seeded Early Composite Best Population Progeny Trial; $E B$ Ex-Bornu; $\mathrm{SPF}_{3}$ Seed Parent $\mathrm{F}_{3}$ Progeny; PBLN Potential B-line Nursery; EERC Extra-Early Restorer Composite; LaGrap Large Grain Population; MC Medium Composite; SDMV SADCC Millet Variety; AIMP Aurangabad ICRISAT Millet Population; ICMS ICRISAT Millet Synthetic; MRC Mandor Restorer Composite; EICP Elite ICRISAT Pollinator.

\section{Micronutrient analysis}

Grain Fe and $\mathrm{Zn}$ densities were analyzed at the Charles Renard Analytical Laboratory, ICRISAT, Patancheru, India following the method described by Wheal et al. (2011). The ground samples were digested in closed tubes; and Fe and $\mathrm{Zn}$ in the digests were analyzed using Inductively Coupled Plasma Optical Emission Spectrometry (ICPOES). Briefly, grain samples were finely ground and oven dried at $60^{\circ} \mathrm{C}$ for $48 \mathrm{~h}$ before analyzing them for Fe and $\mathrm{Zn}$. Ground sample $(0.2 \mathrm{~g})$ was transferred to $25 \mathrm{~mL}$ polyprophelene PPT tubes; digestion was initiated by adding $2.0 \mathrm{~mL}$ of concentrated nitric acid $\left(\mathrm{HNO}_{3}\right)$ and $0.5 \mathrm{~mL}$ of $30 \%$ hydrogen peroxide $\left(\mathrm{H}_{2} \mathrm{O}_{2}\right)$. Tubes were vortexed to ensure the entire sample was wetted, and then predigested overnight at room temperature. Tubes were vortexed again before placing them into the digestion block and initially heated at $80^{\circ} \mathrm{C}$ for 1 hour, followed by digesting at $120^{\circ} \mathrm{C}$ for 2 hours. After digestion, the volume of the digest was made to $25 \mathrm{~mL}$ using distilled water; and the content was agitated for 1 minute by vortex mixer. The digests were filtered and $\mathrm{Fe}$ and $\mathrm{Zn}$ densities were determined using ICP-OES. Care was taken at each step to avoid any contamination of the grains with dust particles and any other extraneous matter (Stangoulis and Sison 2008). The soil samples were analyzed for extractable Fe and $\mathrm{Zn}$ content by Atomic Absorption Spectroscopy (AAS) as described by Lindsay and Norvell (1978). The mean soil Fe and $\mathrm{Zn}$ contents extractable with Diethylene Triamine Pentaacetic Acid (DTPA) were respectively, 13.0 and $7.2 \mathrm{mg} \mathrm{kg}^{-1}$ in the rainy season, and 12.1 and $4.5 \mathrm{mg}$ $\mathrm{kg}^{-1}$ in the summer season. These Fe and $\mathrm{Zn}$ contents in the soil were far above the critical levels required by plants (2.6 to $4.5 \mathrm{mg} \mathrm{kg}^{-1}$ for Fe content, and 0.6 to $1.0 \mathrm{mg} \mathrm{kg}^{-1}$ for $\mathrm{Zn}$ content) (Tisdale et al. 1993; Sahrawat and Wani 2013).

\section{Statistical analysis}

All the data were analyzed using Statistical Analysis Systems (SAS) version 9.2 (SAS Institute Inc. 2004). ANOVA for individual environments and pooled ANOVA over the two environments were performed using Generalized Linear Model procedures following a random-effects model (Steel and Torrie 1980; Hallauer and Miranda 1981; McIntosh 1983). All effects were considered as random in the combined analysis of variance and Satterthwaite's approximation was used to obtain the appropriate degrees of freedom for the synthesized $F$-test (Satterthwaite 1941, 1946). Line $\times$ tester model for female $\times$ male hybrid (Kempthorne 1957) was used to obtain estimates of general combining ability (GCA) for male and female parents as well as specific combining ability (SCA) effects for hybrids. From the analysis of combining ability ANOVA, variances attributed to general combining ability $\left(\sigma_{\text {GCA }}^{2}\right)$ and specific combining 
ability $\left(\sigma_{\text {SCA }}^{2}\right)$ were derived (Kaushik et al. 1984) to estimate the predictability ratio $2 \sigma^{2}{ }_{G C A} /\left(2 \sigma^{2}{ }_{G C A}+\sigma^{2}{ }_{S C A}\right)$ following Baker (1978). The estimates of mid-parent heterosis $(\mathrm{MPH})$ and better-parent heterosis $(\mathrm{BPH})$ were derived for individual environments as well as for the mean of two environments following Hallauer and Miranda (1981). The tests of significance for $\mathrm{MPH}$ and $\mathrm{BPH}$ were done via " $t$ " test. The Pearson correlation coefficient among the traits was calculated using the PROC CORR procedure.

\section{Results}

\section{Parental line performance per se}

There were highly significant differences among the parental lines $(\mathrm{P})$ and their interaction with the environments $(\mathrm{P} \times \mathrm{E})$ for $\mathrm{Fe}$ and $\mathrm{Zn}$ densities and 1000-grain weight (Table 2). For grain yield, only the differences among male parents $(\mathrm{M})$ and interaction of female parents $(F)$ with environment $(F \times E)$ were significant. However, the contribution of parent $\times$ environment interaction to the variability relative to those due to genetic differences among the parental lines was much smaller for Fe (14\%), Zn (18\%) and 1000-grain weight (17\%), and was much higher for grain yield $(66 \%)$. Based on the mean performance over the two environments, large differences were observed among the parental lines for Fe and $\mathrm{Zn}$ densities. The Fe density varied from 30.3 to $77.2 \mathrm{mg} \mathrm{kg}^{-1}$ among the females and 32.0 to $82.1 \mathrm{mg} \mathrm{kg}^{-1}$ among the males, while $\mathrm{Zn}$ density varied from 27.4 to $45.3 \mathrm{mg} \mathrm{kg}^{-1}$ among the females and 29.0 to $55.5 \mathrm{mg} \mathrm{kg}^{-1}$ among the males (Table 3 ). The 1000-grain weight varied from 7.4 to $12.9 \mathrm{~g}$ among the females and from 6.9 to $11.5 \mathrm{~g}$ among the males, while grain yield varied from 1.6 to $3.6 \mathrm{t} \mathrm{ha}^{-1}$ among the females and 1.4 to $3.0 \mathrm{t} \mathrm{ha}^{-1}$ among the males.

\section{Genetic variability}

The differences among hybrids $(\mathrm{H})$ as well their interaction with environment $(\mathrm{H} \times \mathrm{E})$ were highly significant for all four traits (Table 4). However, the contribution of $\mathrm{H} \times \mathrm{E}$ interaction to the variability relative to those due to genetic differences among the hybrids were only 14$16 \%$ for Fe and $\mathrm{Zn}$ density and 1000- grain weight and much higher (41\%) for grain yield. Further partitioning of $\mathrm{H} \times \mathrm{E}$ interaction showed that contribution of $\mathrm{F} \times \mathrm{E}$ interaction to the variability relative to that due to $\mathrm{F}$ effect was 7-11\% for $\mathrm{Fe}$ and $\mathrm{Zn}$ density and 1000-grain weight, while it was much higher (29\%) for grain yield. The contribution of $\mathrm{M} \times \mathrm{E}$ interaction to the variability relative to that due to $M$ effect was 4-6\% for both micronutrients and 1000-grain weight, while it was 24\% for grain yield. Clearly, the variability attributable to interaction of $\mathrm{F}$ and $\mathrm{M}$ with the environments was much smaller as compared to those attributable to $\mathrm{F}$ and $\mathrm{M}$ effects, respectively, for all the traits except for grain yield. The contribution of $\mathrm{F} \times \mathrm{M} \times \mathrm{E}$ interaction to variability relative to that due to $\mathrm{F} \times \mathrm{M}$ interaction was $40-59 \%$ for both micronutrients, 1000-grain weight and grain yield, which were all highly significant. However, the contribution of $\mathrm{F} \times \mathrm{M}$ interaction effect to variability relative to those due to $\mathrm{F}$ and $\mathrm{M}$ effects combined was only about $20 \%$ for Fe and $\mathrm{Zn}$ density and 26\% for 1000-grain weight, while it was about $20 \%$ higher for grain yield. As a result, the variance due to general combining ability $\left(\sigma_{\text {GCA }}^{2}\right)$ was about 4 to 5 times higher than the variance due to specific combining ability $\left(\sigma_{\text {SCA }}^{2}\right)$ for Fe and $\mathrm{Zn}$ density, and more than twice for 1000-grain weight. For grain yield, the $\sigma^{2}$ GCA was $50 \%$ of the $\sigma^{2}$ SCA. This led to predictability ratio close to unity for both micronutrients (0.90 for $\mathrm{Fe}$ and 0.91 for $\mathrm{Zn}$ ). Compared to these

Table 2 Mean square for grain iron (Fe) and zinc (Zn) density, 1000-grain weight (GW) and grain yield (GY) of parental lines

\begin{tabular}{|c|c|c|c|c|c|}
\hline \multirow[t]{2}{*}{ Source of variation } & \multirow[t]{2}{*}{ df } & \multicolumn{4}{|l|}{ Mean square } \\
\hline & & $\mathrm{Fe}\left(\mathrm{mg} \mathrm{kg}^{-1}\right)$ & $\mathrm{Zn}\left(\mathrm{mg} \mathrm{kg}{ }^{-1}\right)$ & $G W(g)$ & $\mathrm{GY}\left(\mathrm{t} \mathrm{ha}^{-1}\right)$ \\
\hline Environment (E) & 1 & $4017.4^{* *}$ & $6002.5^{* *}$ & $16.45^{*}$ & $28.07^{* *}$ \\
\hline Replication /E & 4 & $243.5^{* *}$ & 11.2 & 0.17 & $0.58^{* *}$ \\
\hline Parents (P) & 27 & $958.1^{* *}$ & $324.7^{* *}$ & $18.36^{* *}$ & 1.56 \\
\hline Female (F) & 13 & $988.1^{* *}$ & $222.3^{* *}$ & $13.78^{*}$ & 1.74 \\
\hline Male (M) & 13 & $1001.0^{* *}$ & $410.1^{* *}$ & $14.98^{* *}$ & $1.14^{* *}$ \\
\hline F vs M & 1 & $11.7^{* *}$ & $545.9^{* *}$ & $121.68^{* *}$ & $4.48^{*}$ \\
\hline$P \times E$ & 27 & $137.4^{* *}$ & $56.8^{* *}$ & $3.20^{* *}$ & $1.03^{* *}$ \\
\hline$F \times E$ & 13 & $148.7^{* *}$ & $29.9^{*}$ & $4.20^{* *}$ & $1.89^{* *}$ \\
\hline$M \times E$ & 13 & $136.1^{* *}$ & $74.5^{* *}$ & $1.33^{* *}$ & 0.21 \\
\hline$F$ vs $M \times E$ & 1 & $7.5^{* *}$ & $177.2^{* *}$ & $14.44^{* *}$ & 0.37 \\
\hline Error & 108 & 25.6 & 13.4 & 0.41 & 0.14 \\
\hline
\end{tabular}

${ }^{* * * *}$ Significant at the $\mathrm{P}<0.05$ and 0.01 probability level, respectively. 
Table 3 Performance per se of parental lines and their general combining ability (GCA) effects

\begin{tabular}{|c|c|c|c|c|c|c|c|c|}
\hline \multirow[t]{2}{*}{$I^{a}$} & \multicolumn{4}{|c|}{ Performance per se ${ }^{b}$} & \multicolumn{4}{|l|}{ GCA effects } \\
\hline & $\mathrm{Fe}\left(\mathrm{mg} \mathrm{kg}^{-1}\right)$ & $\mathrm{Zn}\left(\mathrm{mg} \mathrm{kg}^{-1}\right)$ & GW (g) & $G Y\left(t^{-1} a^{-1}\right)$ & $\mathrm{Fe}\left(\mathrm{mg} \mathrm{kg}^{-1}\right)$ & $\mathrm{Zn}\left(\mathrm{mg} \mathrm{kg}^{-1}\right)$ & GW (g) & GY $\left(\mathrm{t} \mathrm{ha}^{-1}\right)$ \\
\hline \multicolumn{9}{|c|}{ Female parents } \\
\hline 1 & 52.6 & 40.0 & 11.0 & 2.9 & $4.1^{* *}$ & $2.5^{* *}$ & $0.6^{* *}$ & $-0.03^{\mathrm{NS}}$ \\
\hline 2 & 30.3 & 27.4 & 7.4 & 2.2 & $-9.5^{* *}$ & $-4.2^{* *}$ & $-1.5^{* *}$ & $0.12^{*}$ \\
\hline 3 & 39.1 & 33.2 & 12.8 & 2.3 & $-4.8^{* *}$ & $-2.9^{* *}$ & $0.4^{* *}$ & $0.04^{\mathrm{NS}}$ \\
\hline 4 & 58.6 & 40.9 & 11.4 & 3.1 & $4.8^{* *}$ & $3.6^{* *}$ & $0.5^{* *}$ & $0.33^{* *}$ \\
\hline 5 & 39.1 & 30.6 & 12.9 & 3.6 & $-5.1^{* *}$ & $-4.0^{* *}$ & $0.1^{\mathrm{NS}}$ & $0.01^{\mathrm{NS}}$ \\
\hline 6 & 77.2 & 45.3 & 10.2 & 2.6 & $7.3^{* *}$ & $2.4^{* *}$ & $-0.3^{* *}$ & $-0.08^{\mathrm{NS}}$ \\
\hline 7 & 43.9 & 37.1 & 10.3 & 3.2 & $0.8^{\mathrm{NS}}$ & $0.1^{\mathrm{NS}}$ & $-0.7^{* *}$ & $0.05^{\mathrm{NS}}$ \\
\hline 8 & 55.3 & 45.0 & 9.2 & 1.6 & $1.8^{* *}$ & $1.6^{* *}$ & $0.7^{* *}$ & $-0.23^{* *}$ \\
\hline 9 & 63.2 & 44.0 & 11.2 & 2.0 & $7.6^{* *}$ & $3.7^{* *}$ & $1.0^{* *}$ & $0.01^{\mathrm{NS}}$ \\
\hline 10 & 51.1 & 40.0 & 10.9 & 2.3 & $-1.8^{* *}$ & $0.5^{\mathrm{NS}}$ & $0.9^{* *}$ & $0.11^{* *}$ \\
\hline 11 & 43.7 & 32.7 & 8.5 & 2.4 & $-3.4^{* *}$ & $-3.7^{* *}$ & $-0.6^{* *}$ & $-0.05^{\mathrm{NS}}$ \\
\hline 12 & 32.1 & 27.6 & 11.0 & 2.8 & $-6.6^{* *}$ & $-2.6^{* *}$ & $-0.4^{* *}$ & $0.29^{* *}$ \\
\hline 13 & 59.8 & 40.7 & 10.8 & 2.2 & $6.4^{* *}$ & $2.5^{* *}$ & $0.5^{* *}$ & $-0.37^{* *}$ \\
\hline 14 & 48.5 & 38.2 & 9.6 & 2.3 & $-1.6^{* *}$ & $0.6^{\mathrm{NS}}$ & $-1.0^{* *}$ & $-0.26^{* *}$ \\
\hline \multicolumn{9}{|c|}{ Male parents } \\
\hline 15 & 43.2 & 41.7 & 9.4 & 2.6 & $-1.4^{* *}$ & $2.1^{* *}$ & $0.7^{* *}$ & $0.22^{* *}$ \\
\hline 16 & 82.1 & 55.5 & 8.8 & 1.8 & $6.4^{* *}$ & $3.1^{* *}$ & $-0.3^{* *}$ & $-0.20^{* *}$ \\
\hline 17 & 63.9 & 49.5 & 11.5 & 2.2 & $9.5^{* *}$ & $6.2^{* *}$ & $0.9^{* *}$ & $-0.44^{* *}$ \\
\hline 18 & 52.1 & 41.5 & 11.2 & 3.0 & $3.9^{* *}$ & $0.5^{\mathrm{NS}}$ & $0.7^{* *}$ & $-0.01^{\mathrm{NS}}$ \\
\hline 19 & 57.1 & 46.0 & 8.5 & 2.4 & $5.6^{* *}$ & $3.8^{* *}$ & $0.1^{\mathrm{NS}}$ & $0.04^{\mathrm{NS}}$ \\
\hline 20 & 41.6 & 33.3 & 11.0 & 2.4 & $-2.5^{* *}$ & $-2.9^{* *}$ & $0.6^{* *}$ & $0.24^{* *}$ \\
\hline 21 & 40.0 & 35.6 & 10.0 & 2.6 & $-2.2^{* *}$ & $-1.2^{* *}$ & $0.2^{* *}$ & $0.10^{*}$ \\
\hline 22 & 46.1 & 37.8 & 7.6 & 2.3 & $1.7^{* *}$ & $1.8^{* *}$ & $0.3^{* *}$ & $-0.07^{\mathrm{NS}}$ \\
\hline 23 & 43.1 & 31.5 & 6.9 & 2.0 & $-9.2^{* *}$ & $-7.8^{* *}$ & $-1.6^{* *}$ & $0.47^{* *}$ \\
\hline 24 & 56.3 & 44.8 & 7.0 & 1.8 & $1.8^{* *}$ & $0.2^{\mathrm{NS}}$ & $-0.8^{* *}$ & $0.05^{\mathrm{NS}}$ \\
\hline 25 & 57.8 & 49.6 & 8.3 & 2.7 & $1.1^{*}$ & $2.8^{* *}$ & $-0.2^{* *}$ & $-0.11^{\mathrm{NS}}$ \\
\hline 26 & 44.4 & 44.4 & 7.5 & 1.7 & $-0.5^{\mathrm{NS}}$ & $1.8^{* *}$ & $-0.1^{\mathrm{NS}}$ & $0.14^{* *}$ \\
\hline 27 & 32.0 & 29.0 & 8.0 & 1.4 & $-7.5^{* *}$ & $-5.0^{* *}$ & $0.4^{* *}$ & $-0.30^{* *}$ \\
\hline 28 & 39.0 & 29.4 & 7.2 & 2.1 & $-6.6^{* *}$ & $-5.1^{* *}$ & $-0.9^{* *}$ & $-0.14^{*}$ \\
\hline $\mathrm{SE} \pm \pm^{c}$ & 2.06 & 1.49 & 0.26 & 0.15 & 0.59 & 0.42 & 0.07 & 0.05 \\
\hline $\operatorname{LSD}^{d}$ & 5.79 & 4.19 & 0.73 & 0.43 & & & & \\
\hline
\end{tabular}

${ }^{\mathrm{a}}$ Refers to Table $1 ;{ }^{\mathrm{b}}$ Mean of two environments (2011 rainy season and 2012 summer season) for grain iron (Fe) and zinc (Zn) density, 1000-grain weight (GW) and grain yield (GY); ${ }^{c} S E$ Standard error; ${ }^{d}$ LSD Least significant difference; ${ }^{*}{ }^{* *}$ Significant at the 0.05 and 0.01 probability level, respectively; ${ }^{N S}$ Non-significant.

micronutrients, the predictability ratio was slightly lower for 1000-grain weight (0.84) and much lower for grain yield $(0.52)$. There were highly significant and high positive correlations between the mid-parental values and hybrid performance per se for Fe density $(r=0.78)$ and Zn density $(\mathrm{r}=0.80)$ (Figure 1$)$. Though highly significant and positive, these correlations were moderate for 1000 -grain weight $(r=0.61)$ and low for grain yield $(\mathrm{r}=0.23)$.

\section{General combining ability (GCA) of parental line}

Amongst the 14 female parents, 6 lines had significant positive GCA for Fe density and most of these had $>55$ $\mathrm{mg} \mathrm{kg}^{-1} \mathrm{Fe}$ density, while 7 females had significant negative GCA and most of these had $<44 \mathrm{mg} \mathrm{kg}^{-1} \mathrm{Fe}$ density (Table 3). The two best general combiners were ICMB 98222 (ID 6) and ICMB 05555 (ID 9) that also had the highest Fe densities of 77.2 and $63.2 \mathrm{mg} \mathrm{kg}^{-1}$, respectively. Among the 14 male parents, 7 lines had significant 
Table 4 Mean square for hybrids and genetic components

\begin{tabular}{|c|c|c|c|c|c|}
\hline \multirow[t]{2}{*}{ Source of variation } & \multirow[t]{2}{*}{ df } & \multicolumn{4}{|l|}{ Mean square $^{a}$} \\
\hline & & $\mathrm{Fe}\left(\mathrm{mg} \mathrm{kg}^{-1}\right)$ & $\mathrm{Zn}\left(\mathrm{mg} \mathrm{kg}^{-1}\right)$ & $\mathrm{GW}(\mathrm{g})$ & GY $\left(\mathrm{t} \mathrm{ha}^{-1}\right)$ \\
\hline Environment (E) & 1 & $22524.5^{* *}$ & $48885.5^{* *}$ & $313.2^{* *}$ & $25.12^{* *}$ \\
\hline Replication/E & 4 & 62.6 & $858.3^{* *}$ & $9.1^{* *}$ & $19.26^{* *}$ \\
\hline Hybrids (H) & 195 & $401.7^{* *}$ & $164.7^{* *}$ & $7.7^{* *}$ & $1.15^{* *}$ \\
\hline Female (F) & 13 & $2574.9^{* *}$ & $720.9^{* *}$ & $48.6^{* *}$ & $3.27^{*}$ \\
\hline Male (M) & 13 & $2470.6^{* *}$ & $1325^{* *}$ & $42.9^{* *}$ & $4.66^{* *}$ \\
\hline $\mathrm{F} \times \mathrm{M}$ & 169 & $77.0^{* *}$ & $32.9^{* *}$ & $1.8^{* *}$ & $0.72^{* *}$ \\
\hline $\mathrm{H} \times \mathrm{E}$ & 195 & $55.4^{* *}$ & $26.2^{* *}$ & $1.1^{* *}$ & $0.47^{* *}$ \\
\hline$F \times E$ & 13 & $174.8^{* *}$ & $62.3^{* *}$ & $5.3^{* *}$ & $0.93^{* *}$ \\
\hline$M \times E$ & 13 & $111.9^{* *}$ & $72.9^{* *}$ & $2.1^{* *}$ & $1.12^{* *}$ \\
\hline $\mathrm{F} \times \mathrm{M} \times \mathrm{E}$ & 169 & $41.6^{* *}$ & $19.7^{*}$ & $0.7^{* *}$ & $0.38^{* *}$ \\
\hline Error & 780 & 29.5 & 15.1 & 0.4 & 0.25 \\
\hline \multicolumn{6}{|l|}{ Genetic components } \\
\hline$\sigma_{G C A}^{2} b$ & & 27.9 & 11.2 & 0.49 & 0.03 \\
\hline$\sigma_{S C A}^{2} c$ & & 5.9 & 2.2 & 0.18 & 0.06 \\
\hline \multicolumn{2}{|c|}{$P R=\left(2 \sigma_{G C A}^{2}\right) /\left(2 \sigma_{G C A}^{2}+\sigma_{S C A}^{2}\right)$} & 0.90 & 0.91 & 0.84 & 0.52 \\
\hline
\end{tabular}

${ }^{\mathrm{a}}$ Grain iron (Fe) and zinc (Zn) density, 1000-grain weight (GW) and grain yield (GY); ${ }^{\mathrm{b}} \sigma_{G C A}^{2}$ Variance attributed to general combining ability; ${ }^{\mathrm{C}} \sigma_{S C A}^{2}$ Variance attributed to specific combining ability; $P R$ Predictability ratio; ${ }^{* * *}$ Significant at the 0.05 and 0.01 probability level, respectively.

positive GCA and most of these had $>56 \mathrm{mg} \mathrm{kg}{ }^{-1} \mathrm{Fe}$ density, while 6 lines had significant negative GCA and all these had $<44 \mathrm{mg} \mathrm{kg}^{-1} \mathrm{Fe}$ density. The two best general combiners were PRP 3 (ID 17) and PRP 2 (ID 16) that also had the highest Fe densities of 63.9 and $82.1 \mathrm{mg} \mathrm{kg}{ }^{-1}$, respectively. Female and male lines considered together, there was highly significant and high positive correlation between the Fe density of parental lines per se and their GCA for this trait $(r=0.86$; $p<0.01)$. Broadly similar patterns were observed for the Zn density. Thus, 6 female parents had significant and positive GCA and all these females had $\geq 40 \mathrm{mg}$ $\mathrm{kg}^{-1} \mathrm{Zn}$ density, while 5 female parents had significant negative GCA and all these females had $<34 \mathrm{mg}$ $\mathrm{kg}^{-1} \mathrm{Zn}$ density. Seven male parents had significant and positive GCA and most of these had $>41 \mathrm{mg} \mathrm{kg}^{-1} \mathrm{Zn}$ density, while 5 male parents had significant negative GCA and all of these had $<36 \mathrm{mg} \mathrm{kg}^{-1} \mathrm{Zn}$ density. There was

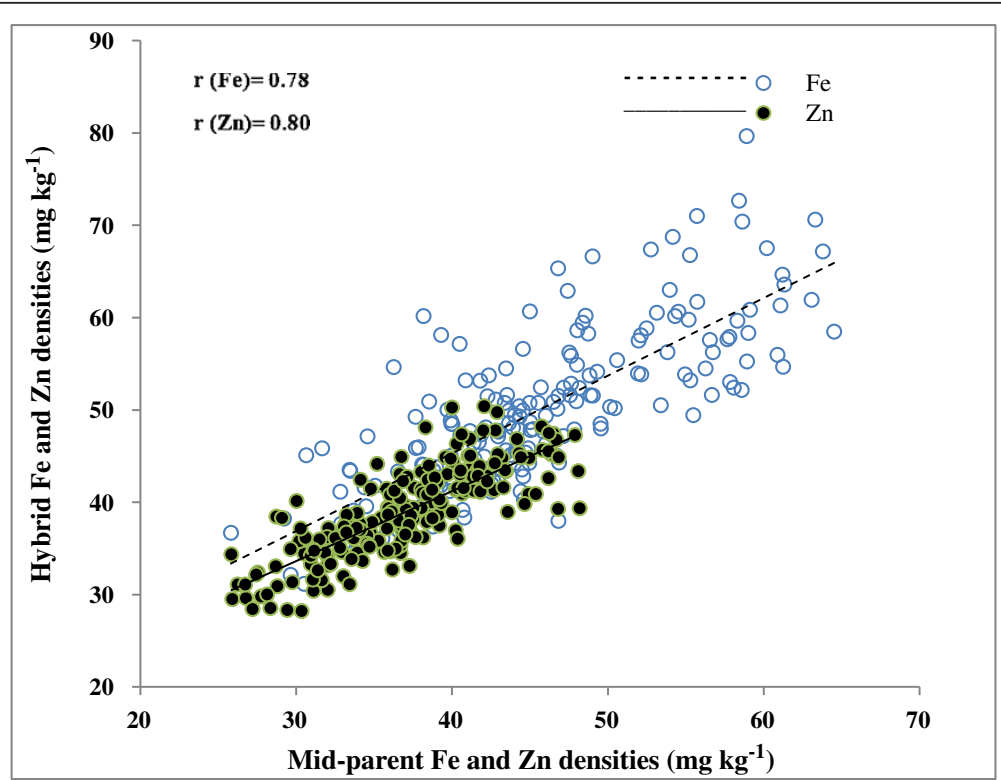

Figure 1 Relationship between mid-parental and hybrid values. Mean of two environment for grain iron (Fe) and zinc ( $Z n$ ) densities. 
highly significant and high positive correlation between the $\mathrm{Zn}$ density of parental lines per se and their GCA for this trait as well $(\mathrm{r}=0.85 ; p<0.01)$. Such a strong relationship between the performance per se of the parental lines and their GCA was not observed for 1000-grain weight $(r=0.59)$ and there was no significant correlation between these two performance parameters for grain yield.

\section{Specific combining ability (SCA) of hybrids}

Amongst 196 hybrids, 51 hybrids had significant SCA for Fe density, of which 28 were positive and 23 were negative (Figure 2). Similarly, 42 hybrids had significant SCA for Zn density, of which 25 were positive and 17 were negative. Of these, 18 hybrids had significant positive SCA effects, both for $\mathrm{Fe}$ and $\mathrm{Zn}$ densities. There were moderate but highly significant positive correlations between performance per se of hybrids and their $\mathrm{SCA}$, both for Fe density $(\mathrm{r}=0.41, p<0.01)$ and $\mathrm{Zn}$ density $(\mathrm{r}=0.42, p<0.01)$. Seventy seven hybrids had significant SCA for 1000-grain weight, of which 37 were positive and 40 were negative. There was moderate but highly significant and positive correlation between 1000-grain weight of the hybrids per se and their SCA $(\mathrm{r}=0.45, p<0.01)$. Fifty six hybrids had significant SCA for grain yield, of which 28 were positive and other 28 were negative, with highly significant and high positive correlation between the performance per se of the hybrids and their SCA $(\mathrm{r}=0.74, p<0.01)$.

\section{Heterosis and hybrid performance}

Averaged over the environments, Fe density among the hybrids varied from 25.8 to $64.5 \mathrm{mg} \mathrm{kg}^{-1}$, but none of the hybrids showed significant better-parent heterosis. However, 62 hybrids had significant mid-parent heterosis, of which 3 were positive and 59 were negative. Top $5 \%$ of the high-Fe hybrids had $60.2-64.5 \mathrm{mg} \mathrm{kg}^{-1} \mathrm{Fe}$ density, which were not significantly different from each other, while the parental lines of these hybrids had large differences, varying from 46.1 to $77.2 \mathrm{mg} \mathrm{kg}^{-1}$ Fe density (Table 5). The perusal of parental combinations of these 10 high-Fe hybrids showed that both parents in all these hybrids had significant positive GCA, with at least one of the parents of all 10 hybrids having high Fe density $\left(\geq 58.6 \mathrm{mg} \mathrm{kg}^{-1}\right)$. In contrast, all the $5 \%$ bottom-Fe hybrids had $\leq 32.8 \mathrm{mg} \mathrm{kg}^{-1} \mathrm{Fe}$ density, which, among themselves, were not significantly different from each other. However, all of these 10 hybrids were significantly different from the top 10 high-Fe hybrids. Both parents of the nine low-Fe hybrids and one of the parents in one hybrid had significant negative GCA, and most of the parents had $<45 \mathrm{mg} \mathrm{kg}^{-1}$ Fe density.

Patterns for $\mathrm{Zn}$ density were similar to those for the $\mathrm{Fe}$ density. The $\mathrm{Zn}$ density among the hybrids varied from 25.8 to $48.2 \mathrm{mg} \mathrm{kg}^{-1}$, but only two of these hybrids had significant better-parent heterosis. Forty five hybrids (23\%) had significant mid-parent heterosis, of which 6 were positive and 39 were negative. The top $5 \%$ high- $\mathrm{Zn}$ hybrids had $46.2-48.2 \mathrm{mg} \mathrm{kg}^{-1} \mathrm{Zn}$ density, which were not significantly different from each other, while the parental lines of these hybrids had large differences, varying from 37.8 to $49.6 \mathrm{mg} \mathrm{kg}^{-1} \mathrm{Zn}$ density (Table 5). The perusal of parental combination of these hybrids showed both parents with significant positive GCA and at least one parents with high $\mathrm{Zn}$ density $\left(\geq 40.7 \mathrm{mg} \mathrm{kg}^{-1}\right)$.

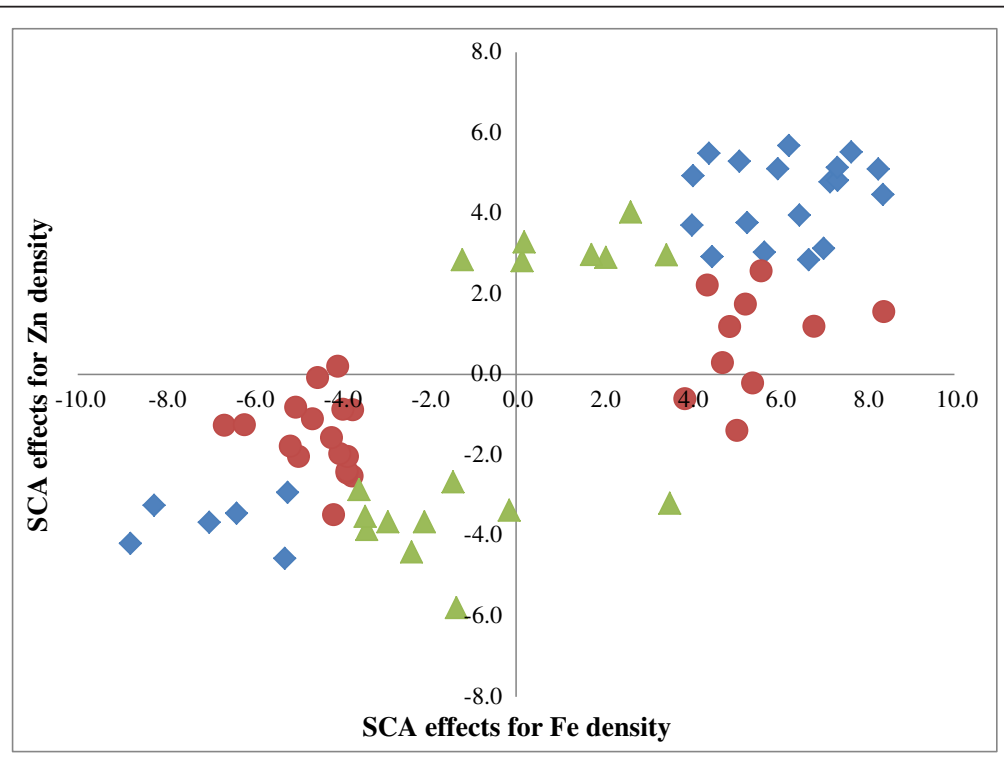

Figure 2 Pearl millet hybrids with significant SCA effects. Significant SCA for Fe density (red circle symbol), for Zn density (yellow triangle symbol) and both for Fe and Zn densities (blue diamond symbol). 
Table 5 Performance per se of hybrids and parental lines, and GCA of parents for $5 \%$ top and $5 \%$ bottom ranking hybrids

\begin{tabular}{|c|c|c|c|c|c|c|c|c|c|c|c|c|c|c|c|}
\hline \multicolumn{8}{|c|}{$\mathrm{Fe}\left(\mathrm{mg} \mathrm{kg}^{-1}\right)$} & \multicolumn{8}{|c|}{$\mathrm{Zn}\left(\mathrm{mg} \mathrm{kg}{ }^{-1}\right)$} \\
\hline \multicolumn{3}{|c|}{ Hybrid $^{a}$} & \multicolumn{3}{|c|}{ Performance per se $e^{b}$} & \multicolumn{2}{|l|}{$\mathrm{GCA}^{\mathrm{c}}$} & \multicolumn{3}{|c|}{ Hybrid $^{a}$} & \multicolumn{3}{|c|}{ Performance per se } & \multicolumn{2}{|l|}{$\mathrm{GCA}^{\mathrm{c}}$} \\
\hline$P_{1}$ & & $P_{2}$ & $F_{1}$ & $P_{1}$ & $P_{2}$ & $P_{1}$ & $P_{2}$ & $P_{1}$ & & $P_{2}$ & $F_{1}$ & $P_{1}$ & $P_{2}$ & $P_{1}$ & $P_{2}$ \\
\hline \multicolumn{16}{|c|}{ Top 5\% hybrids } \\
\hline 13 & $\times$ & 19 & 64.5 & 59.8 & 57.1 & $6.4^{* *}$ & $5.6^{* *}$ & 4 & $\times$ & 22 & 48.2 & 40.9 & 37.8 & $3.6^{* *}$ & $1.8^{* *}$ \\
\hline 6 & $x$ & 19 & 63.8 & 77.2 & 57.1 & $7.3^{* *}$ & $5.6^{* *}$ & 13 & $x$ & 19 & 48.1 & 40.7 & 46.0 & $2.5^{* *}$ & $3.8^{* *}$ \\
\hline 6 & $\times$ & 17 & 63.3 & 77.2 & 63.9 & $7.3^{* *}$ & $9.5^{* *}$ & 8 & $\times$ & 17 & 47.9 & 45.0 & 49.5 & $1.6^{* *}$ & $6.2^{* *}$ \\
\hline 13 & $\times$ & 17 & 63.1 & 59.8 & 63.9 & $6.4^{* *}$ & $9.5^{* *}$ & 1 & $\times$ & 25 & 46.9 & 40.0 & 49.6 & $2.5^{* *}$ & $2.8^{* *}$ \\
\hline 9 & $\times$ & 17 & 61.3 & 63.2 & 63.9 & $7.6^{* *}$ & $9.5^{* *}$ & 13 & $x$ & 22 & 46.8 & 40.7 & 37.8 & $2.5^{* *}$ & $1.8^{* *}$ \\
\hline 9 & $\times$ & 22 & 61.2 & 63.2 & 46.1 & $7.6^{* *}$ & $1.7^{* *}$ & 9 & $\times$ & 17 & 46.7 & 44.0 & 49.5 & $3.7^{* *}$ & $6.2^{* *}$ \\
\hline 6 & $\times$ & 18 & 61.2 & 77.2 & 52.1 & $7.3^{* *}$ & $3.9^{* *}$ & 13 & $\times$ & 17 & 46.5 & 40.7 & 49.5 & $2.5^{* *}$ & $6.2^{* *}$ \\
\hline 4 & $\times$ & 17 & 61.1 & 58.6 & 63.9 & $4.8^{* *}$ & $9.5^{* *}$ & 6 & $x$ & 17 & 46.5 & 45.3 & 49.5 & $2.4^{* *}$ & $6.2^{* *}$ \\
\hline 13 & $x$ & 18 & 60.9 & 59.8 & 52.1 & $6.4^{* *}$ & $3.9^{* *}$ & 4 & $x$ & 17 & 46.4 & 40.9 & 49.5 & $3.6^{* *}$ & $6.2^{* *}$ \\
\hline 6 & $\times$ & 25 & 60.2 & 77.2 & 57.8 & $7.3^{* *}$ & $1.1^{*}$ & 6 & $x$ & 25 & 46.2 & 45.3 & 49.6 & $2.4^{* *}$ & $2.8^{* *}$ \\
\hline \multicolumn{16}{|c|}{ Bottom $5 \%$ hybrids } \\
\hline 5 & $\times$ & 23 & 32.8 & 39.1 & 43.1 & $-5.1^{* *}$ & $-9.2^{* *}$ & 5 & $\times$ & 28 & 28.1 & 30.6 & 29.4 & $-4.0^{* *}$ & $-5.1^{* *}$ \\
\hline 2 & $\times$ & 20 & 31.8 & 30.3 & 41.6 & $-9.5^{* *}$ & $-2.5^{* *}$ & 5 & $\times$ & 27 & 27.8 & 30.6 & 29.0 & $-4.0^{* *}$ & $-5.0^{* *}$ \\
\hline 14 & $\times$ & 23 & 31.7 & 48.5 & 43.1 & $-1.6^{* *}$ & $-9.2^{* *}$ & 3 & $\times$ & 23 & 27.5 & 33.2 & 31.5 & $-2.9^{* *}$ & $-7.8^{* *}$ \\
\hline 10 & $\times$ & 28 & 30.7 & 51.1 & 39.0 & $-1.8^{* *}$ & $-6.6^{* *}$ & 11 & $\times$ & 23 & 27.4 & 32.7 & 31.5 & $-3.7^{* *}$ & $-7.8^{* *}$ \\
\hline 2 & $\times$ & 28 & 30.6 & 30.3 & 39.0 & $-9.5^{* *}$ & $-6.6^{* *}$ & 2 & $\times$ & 28 & 27.2 & 27.4 & 29.4 & $-4.2^{* *}$ & $-5.1^{* *}$ \\
\hline 3 & $\times$ & 27 & 30.5 & 39.1 & 32.0 & $-4.8^{* *}$ & $-7.5^{* *}$ & 12 & $\times$ & 23 & 26.8 & 27.6 & 31.5 & $-2.6^{* *}$ & $-7.8^{* *}$ \\
\hline 2 & $x$ & 27 & 30.5 & 30.3 & 32.0 & $-9.5^{* *}$ & $-7.5^{* *}$ & 3 & $x$ & 27 & 26.7 & 33.2 & 29.0 & $-2.9^{* *}$ & $-5.0^{* *}$ \\
\hline 12 & $\times$ & 27 & 29.7 & 32.1 & 32.0 & $-6.6^{* *}$ & $-7.5^{* *}$ & 5 & $\times$ & 23 & 26.2 & 30.6 & 31.5 & $-4.0^{* *}$ & $-7.8^{* *}$ \\
\hline 2 & $\times$ & 22 & 29.2 & 30.3 & 46.1 & $-9.5^{* *}$ & $1.7^{* *}$ & 2 & $\times$ & 23 & 25.9 & 27.4 & 31.5 & $-4.2^{* *}$ & $-7.8^{* *}$ \\
\hline 2 & $\times$ & 23 & 25.8 & 30.3 & 43.1 & $-9.5^{* *}$ & $-9.2^{* *}$ & 7 & $\times$ & 23 & 25.8 & 37.1 & 31.5 & $0.1^{\mathrm{NS}}$ & $-7.8^{* *}$ \\
\hline$S E \pm^{d}$ & & & 2.22 & 2.06 & 2.06 & 0.59 & 0.59 & & & & 1.59 & 1.49 & 1.49 & 0.42 & 0.42 \\
\hline $\mathrm{LSD}^{\mathrm{e}}$ & & & 6.16 & 5.79 & 5.79 & & & & & & 4.40 & 4.19 & 4.19 & & \\
\hline
\end{tabular}

1-28 ID of inbred lines detailed in the Table $1 ;{ }^{b}$ Mean performance at two environments (2011 rainy season and 2012 summer season) for grain iron (Fe) and zinc (Zn) density. ' $G C A$ General combining ability effects; ${ }^{d}$ SE Standard error; ${ }^{\mathrm{e}}$ LSD Least significant difference; ${ }^{*},{ }^{* *}$ Significant at the 0.05 and 0.01 probability level, respectively; ${ }^{N S}$ Non-significant.

Conversely, $5 \%$ bottom-Zn hybrids had low range of Zn density (25.8-28.1 mg kg-1), which, among themselves, were not significantly different from each other. However, all of these were significantly different from the top 5\% high-Zn hybrids. Both parents of the nine low$\mathrm{Zn}$ hybrids and one parent in one hybrid had significant negative GCA. The 1000-grain weight of hybrids varied from 8.8 to $14.3 \mathrm{~g}$ with significant better- parent heterosis observed in 110 hybrids. Similarly, grain yield of hybrids varied from 2.3 to $5.0 \mathrm{t} \mathrm{ha}^{-1}$, with significant better-parent heterosis observed in 178 hybrids.

\section{Character association}

There was a highly significant and high positive correlation $(\mathrm{r}=0.88, p<0.01)$ between the $\mathrm{Fe}$ and $\mathrm{Zn}$ density in the parental lines as well as in the hybrids (Table 6). Neither Fe nor $\mathrm{Zn}$ densities were correlated with grain yield or with 1000-grain weight in the parental lines. However, both micronutrients had highly significant and moderate positive correlation with 1000-grain weight $(\mathrm{r}=0.42$ and $0.43, p<0.01)$ and significant but week negative correlation with grain yield $(\mathrm{r}=-0.29$ and -0.26 , $p<0.01)$ in the hybrids. Highly significant and moderate positive correlation between 1000-grain weight and grain yield was observed in the parental lines $(\mathrm{r}=0.58, p<0.01)$, but it was not significant in hybrids. Interestingly, highly significant and high positive correlation was observed between the GCA of Fe and GCA of Zn density in parental lines $(\mathrm{r}=0.91, p<0.01)$, and SCA of Fe and SCA of $\mathrm{Zn}$ density in hybrids $(\mathrm{r}=0.71, p<0.01)$. Moderate and highly significant positive correlation was observed between the GCA of 1000-grain weight and Fe density ( $\mathrm{r}=$ $0.51, p<0.01)$ and between the GCA of 1000-grain weight and $\mathrm{Zn}$ density $(\mathrm{r}=0.54, p<0.01)$. The GCA of 
Table 6 Correlation coefficient among traits in hybrids (above diagonal) and parents (below diagonal)

\begin{tabular}{lllll}
\hline Trait $^{\mathbf{a}}$ & $\mathbf{F e}\left(\mathbf{m g ~ k g}^{-\mathbf{1}}\right)$ & $\mathbf{Z n}\left(\mathbf{m g ~ k g}^{-\mathbf{1}}\right)$ & $\mathbf{G Y}\left(\mathbf{t ~ h a}^{-\mathbf{1}}\right)$ & $\mathbf{G W}(\mathbf{g})$ \\
\hline $\mathrm{Fe}$ & 1 & $0.88^{* *}\left(0.71^{* *}\right)$ & $-0.29^{* *}\left(-0.13^{\mathrm{NS}}\right)$ & $0.42^{* *}\left(0.003^{\mathrm{NS}}\right)$ \\
$\mathrm{Zn}$ & $0.88^{* *}\left(0.91^{* *}\right)^{\mathrm{b}}$ & 1 & $-0.26^{* *}\left(-0.14^{\mathrm{NS}}\right)$ & $0.43^{* *}\left(-0.02^{\mathrm{NS}}\right)$ \\
$\mathrm{GY}$ & $-0.11^{\mathrm{NS}}\left(-0.41^{*}\right)$ & $-0.18^{\mathrm{NS}}\left(-0.35^{\mathrm{NS}}\right)$ & 1 & $-0.05^{\mathrm{NS}}\left(0.21^{* *}\right)$ \\
$\mathrm{GW}$ & $0.11^{\mathrm{NS}}\left(0.51^{* *}\right)$ & $0.002^{\mathrm{NS}}\left(0.54^{* *}\right)$ & $0.58^{* *}\left(-0.21^{\mathrm{NS}}\right)$ & 1 \\
\hline
\end{tabular}

${ }^{a}$ Grain iron (Fe) and zinc (Zn) density, 1000-grain weight (GW) and grain yield (GY); ${ }^{b}$ Values outside the parentheses are phenotypic correlations for performance per se and values within the parentheses are correlations between GCA effects in parents and between SCA effects in hybrids; ${ }^{* * *}$ Significant at the 0.05 and 0.01 probability level, respectively; ${ }^{N S}$ Non-significant.

grain yield had significant but moderate negative correlation with Fe density $(\mathrm{r}=-0.41, p<0.01)$, but it was uncorrelated with GCA of Zn density. The SCAs of both micronutrients were not correlated with the SCAs of either 1000-grain weight or grain yield, but there was highly significant and weak positive correlation between the SCA of 1000-grain weight and grain yield $(\mathrm{r}=0.21, p<0.01)$.

\section{Discussion}

Parental lines (both female and male parents) of diverse parentage included in this study had highly significant and large differences for Fe and Zn densities, and 1000grain weight, with only male parents having significant differences for grain yield. Hybrids produced from female $\times$ male crosses had, as expected, highly significant and large differences for all four traits. The variability among the hybrids attributable to general combining ability $\left(\sigma_{\text {GCA }}^{2}\right)$ was $4-5$ times greater than the variability attributable to specific combining ability $\left(\sigma^{2}{ }_{S C A}\right)$ for Fe and $\mathrm{Zn}$ densities, with the predictability ratio being closer to unity for both micronutrients. This showed that both Fe and $\mathrm{Zn}$ densities were predominantly under additive genetic control. Earlier studies in pearl millet (Velu et al. 2011b; Govindaraj et al. 2013), rice (Zhang et al. 2004) and maize (Gorsline et al. 1964; Arnold and Bauman 1976; Brkic et al. 2003; Long et al. 2004; Chen et al. 2007) have also reported these micronutrients largely under additive genetic control. Highly significant and high positive correlations between performance per se of the hybrids and mid-parental values provided further support for these micronutrients being largely under additive genetic control. Similar results in pearl millet have been reported in earlier studies (Velu et al. 2011b; Govindaraj et al. 2013). The predominance of additive gene action would make recurrent selection for intra-population improvement and open-pollinated variety (OPV) development highly effective. However, development of hybrids with high $\mathrm{Fe}$ and $\mathrm{Zn}$ density would require that the same genes for $\mathrm{Fe}$ and $\mathrm{Zn}$ density are incorporated into both parental lines of the hybrids, since hardly any hybrid was found transgressing the parental lines for higher Fe density (i.e., no better-parent heterosis). About 30\% of the hybrids, had significant mid-parent heterosis for Fe density; and $23 \%$ hybrids had significant mid-parent heterosis for
Zn density, which is not unexpected as significant, albeit low, variability among the hybrids attributable to $\sigma^{2}$ SCA had been observed for both micronutrients. Most of these mid-parent heterosis values were in the negative direction, indicating the involvement of genes other than those with additive gene action where alleles determining lower $\mathrm{Fe}$ and $\mathrm{Zn}$ densities are partially dominant. It is also likely that effects of genes acting additively for Fe and $\mathrm{Zn}$ densities are influenced by genetic backgrounds, the more so in the negative direction, mimicking low levels of partial dominance. Iniadi germplasm so far has been found to be the best source of high Fe and Zn density in pearl millet (Velu et al. 2011b; Rai et al. 2012; Govindaraj et al. 2013). Thus, taking into consideration the additive gene action, if the same source is used to introgress the genes responsible for Fe and $\mathrm{Zn}$ density in both parental lines, it is likely to reduce the genetic diversity between B-lines (and consequently A-lines) and R-lines for other traits. This would potentially lead to reduction in heterosis for grain yield and other traits of agronomic and economic importance, which are predominantly under non-additive gene effects. Genomics approaches for selective introgression of genes for $\mathrm{Fe}$ and $\mathrm{Zn}$ density in the parental lines without disrupting the diversity between them for other traits can play a major role in breeding high-yielding hybrids with higher levels of Fe and $\mathrm{Zn}$ densities.

Hybrids in the top 5\% ranks for Fe density involved generally both and always at least one parent that had positive GCA for this trait. A similar pattern was observed for $\mathrm{Zn}$ density where at least one of the parents of the top ranking $5 \%$ hybrids was a positive general combiner. There were highly significant and high positive correlations between performance per se of the inbred lines and their GCA both for Fe density and Zn density, indicating that selection for performance per se would be highly effective in selecting for the GCA of these micronutrients. Interestingly, GCA of Fe density also had highly significant and high positive correlation with the GCA of $\mathrm{Zn}$ density, which was not unexpected considering that the performance per se of the parental lines and their GCAs were highly significantly and positively correlated, and there was highly significant and high positive correlation between the Fe and $\mathrm{Zn}$ densities in the parental lines as well as in the hybrids. 
Similar relationships between these micronutrients have been reported in earlier studies on pearl millet (Velu et al. 2008a, 2008b; Gupta et al. 2009; Rai et al. 2012; Govindaraj et al. 2013), and in other cereals, such as sorghum (Ashok Kumar et al. 2010, 2013), maize (Arnold et al. 1977; Oikeh et al. 2003, 2004), rice (Stangoulis et al. 2007; Anandan et al. 2011), wheat (Garvin et al. 2006; Peleg et al. 2009; Zhang et al. 2010; Velu et al. 2011a), and finger millet (Upadhyaya et al. 2011). Genomic studies in wheat (Peleg et al. 2009; Singh et al. 2010), rice (Stangoulis et al. 2007), common bean (Cichy et al. 2009; Blair et al. 2009) and pearl millet (Kumar 2011) have identified common and overlapping quantitative trait loci (QTL) for Fe and Zn densities. Thus, the patterns for Fe and $\mathrm{Zn}$ densities were similar whether it is with respect to the nature of genetic variability and heterosis, or with respect to the relationship between the parental lines and their GCA. This could likely result from similar physiological processes involved at one or more stages from soil uptake to loading in the grains, and tight linkage of some of the genes contributing to the major part of genetic variability for these micronutrients. It would appear that effective simultaneous selection for Fe and $\mathrm{Zn}$ densities in pearl millet can be made with respect to all these performance parameters, and application of genomics tools can significantly accelerate this process.

High predictability ratio and highly significant and high positive correlation between the mid-parental values and hybrid performance was indicative of predominantly additive genetic variation for 1000-grain weight. In contrast, moderate predictability ratio and low, though significant, correlation between the mid-parental values and hybrid performance was indicative of predominantly non-additive genetic variation for grain yield. Several studies in pearl millet have reported predominantly additive genetic variability for 1000-grain weight and predominantly non-additive genetic variability for grain yield (Khairwal et al. 1999). The relative importance of additive and non-additive variation for these two traits were also reflected in heterosis patterns as $56 \%$ of the hybrids had significant better-parent heterosis with highly significant but moderate correlation between the hybrid performance per se and SCA for 1000-grain weight. In comparison, 91\% hybrids showed significant better-parent heterosis for grain yield and there was highly significant and high positive correlation between the performance of hybrids per se and their SCA.

Both Fe and $\mathrm{Zn}$ densities were not correlated either with 1000-grain weight or with grain yield in the parental lines, which indicates that parental lines with high Fe and $\mathrm{Zn}$ density can be developed without compromising on grain size and grain yield. In hybrids, however, Fe and $\mathrm{Zn}$ densities had a highly significant and moderate positive correlation with 1000-grain weight. While some of the earlier studies in pearl millet (Velu et al. 2007, 2008a, 2008b) have reported significant positive correlation of Fe and $\mathrm{Zn}$ with 1000-grain weight, other studies have reported no correlation of $\mathrm{Fe}$ and $\mathrm{Zn}$ densities with 1000-grain weight ( Gupta et al. 2009; Rai et al. 2012). This indicated that high Fe and Zn densities can be easily combined with large grain size. The Fe and $\mathrm{Zn}$ densities had highly significant though weak negative correlation with grain yield. Earlier studies in pearl millet hybrids (Rai et al. 2012), wheat (Garvin et al. 2006; Morgounov et al. 2007; Shi et al. 2008; Zhao et al. 2009), sorghum (Reddy et al. 2005) and maize (Bänziger and Long 2000) reported significant negative relationship between micronutrients and yield. In the present study, however, these correlations were weak enough in the magnitude, indicating that if these were the results of adverse genetic associations, highyielding hybrids with high Fe and $\mathrm{Zn}$ densities can be bred by making selection for these traits in larger segregating populations and progenies as compared to those used for breeding for grain yield alone. These weak negative relationships resulting from dilution effects, however, cannot be ruled out and, therefore, this subject merits further investigation.

\section{Conclusions}

Genetic variability both for Fe and $\mathrm{Zn}$ densities was predominantly under additive genetic control, implying that intra-population improvement for these micronutrients is likely to be highly effective. However, breeding hybrids with high levels of $\mathrm{Fe}$ and $\mathrm{Zn}$ densities will require incorporating them in both parental lines, and application of genomics tools may significantly accelerate this process. Highly significant and high positive correlation between performance per se of parental line and their general combining ability (GCA) both for Fe and $\mathrm{Zn}$ densities showed that parental lines of potential hybrids with high GCA can be effectively selected based on their performance per se, thus enhancing the breeding efficiency. Lack of correlation of Fe and $\mathrm{Zn}$ densities with grain yield in inbred lines, but significant negative (although low) correlation in hybrids merits further investigation as these results have direct bearing on the efficiency of breeding high-yielding hybrids with high levels of Fe and $\mathrm{Zn}$ densities.

\section{Abbreviations \\ Fe: Iron; Zn: Zinc; PR: Predictability ratio; GCA: General combining ability; SCA: Specific combining ability; r: Correlation coefficient.}

\section{Competing interests}

The authors declare that they have no competing interests.

\section{Authors' contributions}

AK carried out all aspects of the experiment from seed preparation to planting, data recording, grain sample preparation for laboratory analysis, statistical analysis, and preparation of final draft of the manuscript. KNR as 
co-advisor of this research, provided seed materials, helped in design of the experiment with respect to crossing and field layout, suggested the analyses required, and helped AK during the revision process to develop final version of the manuscript. KR as major advisor of this research, helped in developing the framework of this research, and made suggestions for two rounds of revision of the draft prepared by AK. MG coordinated with the analytical laboratory for analysis of grain samples for Fe and Zn densities, and assisted in the interpretation of results. KLS supervised the analysis of grain samples for Fe and $\mathrm{Zn}$ densities in his laboratory. ASR assisted AK in crop management and data recording. All authors read and approved the final manuscript.

\section{Authors' details}

AK: Ph.D. Research Scholar and KR (Ph.D.): Associate Professor at Professor Jayashankar Telangana State Agricultural University, Rajendranagar, Telangana, India; KNR (Ph.D.) and MG (Ph.D.): Millet Breeders; KLS (Ph.D.): Soil Scientist, ASR (M.Sc.): Scientific Officer at International Crops Research Institute for the Semi-Arid Tropics (ICRISAT), Telangana, India.

\section{Acknowledgements}

The research reported here forms part of Ph.D. thesis of Anand Kanatti, submitted to Professor Jayashankar Telangana State Agricultural University, Hyderabad 500 030, Telangana, India. It was supported by a grant from HarvestPlus Challenge Program of the CGIAR.

\section{Author details}

${ }^{1}$ International Crops Research Institute for Semi-Arid Tropics (ICRISAT), Patancheru, Hyderabad 502324, Telangana, India. ${ }^{2}$ Department of Genetics and Plant Breeding, College of Agriculture, Professor Jayashankar Telangana State Agricultural University, Rajendranagar, Hyderabad 500 030, Telangana, India.

\section{Received: 15 July 2014 Accepted: 10 December 2014}

\section{Published: 26 December 2014}

\section{References}

Anandan A, Rajiv G, Eswaran R, Prakash M (2011) Genotypic variation and relationships between quality traits and trace elements in traditional and improved rice (Oryza sativa L.) genotypes. J Food Sci 76(4):H122-H130, doi:10.1111/ j.1750-3841.2011.02135.x

Arnold JM, Bauman LF (1976) Inheritance and interrelationships among maize kernel traits and elemental contents. Crop Sci 16:439-440, doi:10.2135/ cropsci1976.0011183X00 1600030034x

Arnold JM, Bauman LF, Aycock HS (1977) Interrelations among protein, lysine, oil, certain mineral element concentrations, and physical kernel characteristics in two maize populations. Crop Sci 17:421-425

Ashok Kumar A, Reddy BVS, Sahrawat KL, Ramaiah B (2010) Combating micronutrient malnutrition: Identification of commercial sorghum cultivars with high grain iron and zinc. J SAT Agric Res 8:1-5

Ashok Kumar A, Reddy BVS, Ramaiah B, Sahrawat KL, Pfeiffer WH (2013) Gene effects and heterosis for grain iron and zinc concentration in sorghum [Sorghum bicolor (L.) Moench]. Field Crop Res 146:86-95, DOl: 10.1016/j. fcr.2013.03.001

Baker RJ (1978) Issues in diallel analysis. Crop Sci 18(4):533-536

Bänziger M, Long J (2000) The potential for increasing the iron and zinc density of maize through plant breeding. Food Nutr Bull 21:397-400

Blair MW, Astudillo C, Grusak M, Graham R, Beebe S (2009) Inheritance of seed iron and zinc content in common bean (Phaseolus vulgaris L.). Mol Breed 23:197-207

Bouis HE (2003) Micronutrient fortification of plants through plant breeding: can it improve nutrition in man at low cost? Proc Nutr Soc 62:403-411

Brkic I, Simic D, Zdunic Z, Jambrovic A, Ledencan T, Kovacevic V, Kadar I (2003) Combining abilities of Corn-Belt inbred lines of maize for mineral content in grain. Maydica 48:293-297

Chen F, Chun L, Song J, Mi G (2007) Heterosis and genetic analysis of iron concentration in grains and leaves of maize. Plant Breed 126:107-109, doi:10.1111/j.1439-0523.2006.01289.x

Cichy KA, Caldas GV, Snapp SS, Blair MW (2009) QTL analysis of seed iron, zinc, and phosphorus levels in an Andean bean population. Crop Sci 49:1742-1750, doi:10.2135/cropsci2008.10.0605
Garvin DF, Welch RM, Finley JW (2006) Historical shifts in the seed mineral micronutrient concentration of US hard red winter wheat germplasm. J Sci Food Agric 86:2213-2220

Gorsline GW, Thomas WI, Baker DE (1964) Inheritance of P, K, mg, Cu, B, Zn, Mn, $\mathrm{Al}$, and Fe concentrations by corn (Zea mays L.) leaves and grain. Crop Sci 4:207-210

Govindaraj M, Rai KN, Shanmugasundaram P, Dwivedi SL, Sahrawat KL, Muthaiah AR, Rao AS (2013) Combining ability and heterosis for grain iron and zinc densities in pearl millet. Crop Sci 53:507-517, doi:10.2135/cropsci2012.08.0477

Gupta SK, Velu G, Rai KN, Sumalini K (2009) Association of grain iron and zinc content with grain yield and other traits in pearl millet (Pennisetum glaucum (L.) R. Br.). Crop Improv 36:4-7

Hallauer AR, Miranda JB (1981) Quantitative genetics in maize breeding, 1st edn. lowa State University Press, Ames

Kaushik LS, Singh DP, Paroda RS (1984) Line $\times$ tester analysis for fixed effect model in cotton (Gossypiumhirsutum L.). Theor Appl genet 68:487-491

Kempthorne O (1957) An introduction to genetic statistics. John Wiley \& Sons, New York

Khairwal IS, Rai KN, Andrews DJ, Harinarayana G (eds) (1999) Pearl millet breeding. Oxford and IBH Publishing, New Delhi

Kumar S (2011) Development of new mapping population and marker-assisted improvement of iron and zinc grain density in pearl millet [Pennisetum glaucum (L.) R. Br.]. Dissertation, Swami Keshwanand Rajasthan Agricultural University, Bikaner

Lindsay WL, Norvell WA (1978) Development of a DTPA test for zinc, iron, manganese and copper. Soil Sci Soc Am J 42:421-428

Long JK, Banziger M, Smith ME (2004) Diallel analysis of grain iron and zinc density in southern african-adapted maize inbreds. Crop Sci 44:2019-2026

McIntosh MS (1983) Analysis of combined experiments. Agron J 75:153-155

Morgounov A, Gomez-Becerra HF, Abugalieva A, Dzhunusova M, Yessimbekova M, Muminjanov H, Zelenskiy Y, Ozturk L, Cakmak I (2007) Iron and zinc grain density in common wheat grown in central Asia. Euphytica 155:193-203

Oikeh SO, Menkir A, Maziya-Dixon B, Welch R, Glahn RP (2003) Assessment of concentrations of iron and zinc and bioavailable iron in grains of early maturing tropical maize varieties. J Agric Food Chem 51:3688-3694, doi:10.1021/jf0261708

Oikeh SO, Menkir A, Maziya-Dixon B, Welch RM, Glahn RP, GauchJr G (2004) Environmental stability of iron and zinc concentrations in grain of elite early-maturing tropical maize genotypes grown under field conditions. J Agric Sci 142:543-551, doi:10.1017/S0021859604004733

Parthasarathy Rao P, Birthal PS, Reddy BVS, Rai KN, Ramesh S (2006) Diagnostics of sorghum and pearl millet grains-based nutrition in India. Int Sorghum Millets Newsl 47:93-96

Peleg Z, Cakmak I, Ozturk L, Yazici A, Jun Y, Budak H, Korol AB, Fahima T, Saranga $Y$ (2009) Quantitative trait loci conferring grain mineral nutrient concentrations in durum wheat $\times$ wild emmer wheat RIL population. Theor Appl genet 119:353-369, doi:10.1007/s00122-009-1044-z

Rai KN, Govindaraj M, Rao AS (2012) Genetic enhancement of grain iron and zinc content in pearl millet. Qual Assur Saf Crop 4:119-125, doi:10.1111/j.1757837X.2012.00135.x

Rai KN, Yadav OP, Rajpurohit BS, Patil HT, Govindaraj M, Khairwal IS, Rao AS, Shivade H, Pawar VY, Kulkarni MP (2013) Breeding pearl millet cultivars for high iron density with zinc density as an associated trait. J SAT Agric Res 11:1-7

Reddy BVS, Ramesh S, Longvah T (2005) Prospects of breeding for micronutrients and $\beta$-carotene-dense sorghums. Int Sorghum Millets Newsl 46:10-14

Sahrawat KL, Wani SP (2013) Soil testing as a tool for on-farm fertility management: experience from the semi-arid zone of India. Commun Soil Sci Plant Anal 44:1011-1032

SAS Institute Inc. (2004) SAS/STAT 9.2 user's guide. SAS Institute Inc, Cary

Satterthwaite FE (1941) Synthesis of variance. Psychometrika 6:309-316

Satterthwaite FE (1946) An approximate distribution of estimates of variance components. Biometrics Bull 2:110-114

Shi R, Li H, Tong Y, Jing R, Zhang F, Zou C (2008) Identification of quantitative trait locus of zinc and phosphorus density in wheat (Triticum aestivum L.) grain. Plant Soil 306:95-104

Singh K, Chhuneja P, Tiwari VK, Rawat N, Neelam K, Aggarwal R, Malik S, Keller B, Dhaliwal HS (2010) Mapping of QTL for grain iron and zinc content in diploid A genome wheat and validation of these loci in $U$ and $S$ genomes. Paper presented at: Plant and Animal genomes XVIII Conference. San Diego

Stangoulis J, Sison C (2008) Crop sampling protocols for micronutrient analysis. Harvest Plus Tech Monogr Ser 7 
Stangoulis JCR, Huynh BL, Welch RM, Choi EY, Graham RD (2007) Quantitative trait loci for phytate in rice grain and their relationship with grain micronutrient content. Euphytica 154:289-294, doi:10.1007/s10681-006-9211-7

Steel RDG, Torrie JH (1980) Principles and procedures of statistics: a biometrical approach, 2nd edn. McGraw-Hill, Inc, New York, NY

Stein AJ, Meenakshi JV, Qaim M, Nestel P, Sachdev HPS, Bhutta ZA (2005) Analyzing the health benefits of biofortified staple crops by means of the disability-adjusted life years approach: a handbook focusing on iron, zinc and vitamin A. Harvest Plus Technical Monograph 4. IFPRI and CIAT, Washington, http://www.harvestplus.org/sites/default/files/tech04.pdf

Tisdale SL, Nelson WL, Beaton JB (1993) Soil fertility and fertilizers, 5th edn. Macmillan Pub. Co, New York

Upadhyaya HD, Ramesh S, Shivali S, Singh SK, Varshney SK, Sarma NDRK, Ravishankar CR, Narasimhudu Y, Reddy VG, Sahrawat KL, Dhanalakshmi TN, Mgonja MA, Parzies HK, Gowda CLL, Singh S (2011) Genetic diversity for grain nutrients contents in a core collection of finger millet (Eleusine coracana (L.) gaertn.) germplasm. Field Crop Res 121:42-52, doi:10.1016/j.fcr.2010.11.017

Velu G, Rai KN, Muralidharan V, Kulkarni VN, Longvah T, Raveendran TS (2007) Prospects of breeding bio fortified pearl millet with high grain iron and zinc content. Plant Breed 126:182-185, doi:10.1111/j.1439-0523.2007.01322.x

Velu G, Rai KN, Sahrawat KL, Sumalini K (2008a) Variability for grain iron and zinc contents in pearl millet hybrids. J SAT Agric Res 6:1-4

Velu G, Rai KN, Sahrawat KL (2008b) Variability for grain iron and zinc content in a diverse range of pearl millet populations. Crop Improv 35:186-191

Velu G, Ortiz-Monasterio I, Singh RP, Payne T (2011a) Variation for grain micronutrients in wheat core collections accession of diverse origin. Asian $J$ Crop Sci 3:43-48, doi:10.3923/ ajcs.2011.43.48

Velu G, Rai KN, Muralidharan V, Longvah T, Crossa J (201 1b) Gene effects and heterosis for grain iron and zinc density in pearl millet (Pennisetum glaucum (L.) R. Br). Euphytica 180:251-259, doi:10.1007/s10681-011-0387-0

Wheal MS, Fowles TO, Palmer LT (2011) A cost-effective acid digestion method using closed polypropylene tubes for inductively coupled plasma optical emission spectrometry (ICP-OES) analysis of plant essential elements. Anal Methods 3:2854-2863

WHO (2002) Reducing risks and promoting healthy life. The World Health Report. World Health Organization, Geneva, pp 168-233

Yadav OP, Rai KN, Rajpurohit BS, Hash CT, Mahala RS, Gupta SK, Shetty HS, Bishnoi HR, Rathore MS, Kumar A, Sehgal S, Raghvani KL (2012) Twenty-five years of pearl millet improvement in India. All India Coordinated Pearl Millet Improvement Project, Jodhpur

Zhang MW, Guo BJ, Peng ZM (2004) Genetic effects on Fe, Zn, Mn and P contents in Indica black pericarp rice and their genetic correlations with grain characteristics. Euphytica 135:315-323

Zhang Y, Song Q, Yan J, Tang J, Zhao R, Zhang Y, He Z, Zou C, Ortiz-Monasterio I (2010) Mineral element concentrations in grains of Chinese wheat cultivars. Euphytica 174:303-313, doi:10.1007/s10681-009-0082-6

Zhao FJ, Su YH, Dunham SJ, Rakszegi M, Bedo Z, McGrath SP, Shewry PR (2009) Variation in mineral micronutrient concentrations in grain of wheat lines of diverse origin. J Cereal Sci 49:290-295

doi:10.1186/2193-1801-3-763

Cite this article as: Kanatti et al:: Grain iron and zinc density in pearl millet: combining ability, heterosis and association with grain yield and grain size. SpringerPlus 2014 3:763.

\section{Submit your manuscript to a SpringerOpen ${ }^{\circ}$ journal and benefit from:}

- Convenient online submission

- Rigorous peer review

- Immediate publication on acceptance

- Open access: articles freely available online

- High visibility within the field

- Retaining the copyright to your article

Submit your next manuscript at $\gg$ springeropen.com 